\title{
Folk botanical nomenclature - between structured and non-structured lexis
}

\author{
Oana Zamfirescu* \\ “A. Philippide” Institute of Romanian Philology, Str. Th. Codrescu 2, 700481 Iași, Romania
}

\section{Article info}

History:

Published December 23, 2016

Accepted January 23, 2017

Received March 23, 2017

Key words:

lexematics

nomenclature

folk plant names

\begin{abstract}
This article aims to investigate the status of folk botanical nomenclature from the perspective of the lexematic theory, a theory developed by Eugeniu Coseriu. The linguist believes that terminologies (folk and scientific) represent objective and conventional classifications that fall under the order of reality. They are a part of the non-structured lexis and not a part of the structured one. The features that situate this nomenclature in the non-structured lexis and ones that situate it in the structured lexis are established on the basis of the material made available by various sources (dictionaries, encyclopædias, different works containing plant names form our country). After the consultation of the sources, the conclusion is that folk plant names are situated at the border line between common language and scientific terminology.
\end{abstract}

\section{Preliminaries. Terminology from the perspective of lexematics}

E. Coseriu's theory about terminology is presented in two of his works: Principios de semántica estructural and Palabras, cosas y términos (see also Florescu, 2011). The first of these works consists of a series of studies that aim to present systematically the issues related to the structure of the lexis. Among them there is the study called Introducción al estudio estructural del léxico, which contains the series of distinctions made by E. Coseriu, distinctions used at the structural analysis of the lexis. These distinctions are: words and things, primary language and metalanguage, synchrony and diachrony, the technique of discourse and repeated discourse, historical language and functional language, system and norm, designation and signification. The first of these distinctions, the one between words and things, is the one that investigates the status of terminologies. The author asserts that terminologies are "simples <nomenclaturas> enumerativas que corresponden a delimitaciones en los objetos" (Coseriu, 1986, p. 96). Thus, the common/structured lexis (which contains words) is separated from the terminological lexis (which contains terms). Given this distinction, the terms (meaning the words belonging to the lexis of science and technique/non-structured lexis) and the words (belonging to the part of the lexis that can be subjected to the structural analysis) are treated as language units with opposite properties. The first difference between terms and words is represented by the specific manner of structuring within each of this two categories. The terms refer to the typical feature of things and represent objective classifications of the extra-linguistic world. Their manner of "structuring" does not correspond to language and its rules; it corresponds to the requirements of the domains of science and technology in which they are used, changes according to the progress of these domains and it is not subjected to language change. The knowledge of the signifiers is directly proportional to the knowledge of the scientific and technological domains that use them and is independent from language knowledge (also see Vascenco, 1975, p. 14-15). Words, on the other hand, belong to the common vocabulary. Accordingly, they depend on the language rules and their structuring is done through the relationships between their meanings. This means that the structures specific to the common language are the semantic ones. In Palabras, cosas y términos, E. Coșeriu provides the next example: "Así,

*Email address: zamfirescuo@yahoo.com. 
el significado de parole en francés lo define la semántica estructural del francés por las oposiciones en las que parole funciona en esta lengua, o sea, con respecto a los significados de mot, discours, propos, boniment, devise, sentence, expression, langage, etc., mientras que el término parole en la lingüistica saussuriana lo define esta lingüistica por una delimitación en las cosas mismas y prescindiendo de las oposiciones en las que esta palabra funciona en francés; mejor dicho, lo que en este caso se defien es la cosa <parole> y a esta cosa se le atribuye la designación parole" (Coseriu, 1987, p. 181).

The second element that separates the two categories of linguistic signs refers to the relationships of designation and signification. In the case of the terms, which are simple substitutes for things, the two relationships correspond. In the case of words, which are part of the common vocabulary, the two relationships are different from each other.

The third element which distinguishes the two types of lexis represents the consequence of the dissolution of the border between designation and signification in the case of terms. As a result, the technical and the scientific delimitations are made in the objective reality and the linguistic ones are made in the intuition of the reality, at the level of signification (Coseriu, 1987, p. 182-183). The fourth element concerning the opposition between terminological lexis and common lexis refers to the type of terminological delimitations. They are precise and closely related to the designated extra-linguistic element (meaning corporeal or abstract/imaginary objects).

The fifth element taken into account by the linguist refers to the type of oppositions that are characteristic to the two areas of the lexis. In the case of the terminological lexis, the oppositions are exclusive, meaning that each term is independent and in opposition with other terms. The oppositions established within the common vocabulary are inclusive, which means that the unmarked term can encapsulate the marked one (for example, the word "day" can be contrary to "night", but can also include "night", signifying "day + night"; also, in the common language, the masculine can sometimes include the feminine: "fiancé" + "fiancée" = "fiancées", Coseriu, 1986, p. 97). The sixth criterion regards their translatability. The terms specific to science and technology are easily translated because they are related to the level of expression and not to the level of meaning. Therefore, at least in theory, they can be easily translated (Coseriu, 1986, p. 98). Translation is difficult in the case of the words that belong to the common language because it involves the substitution between the signifies of two languages (Coseriu, 1986, p. 98).

Within the framework of the lexematic theory of E. Coseriu, the conclusion is obvious: terminologies (scientific and technological terminologies and folk terminologies as: the agricultural terminology, the horse and plow nomenclatures, the botanical classifications) are simply objective, conventional classifications, included in the order of reality. They imply an organization (scientific or empirical) based on extra-linguistic criteria, on the knowledge of things. The delimitations are made in the structure of things and not in the linguistic material.

\section{Folk botanical nomenclature}

Romanian folk plant names constitute a nomenclature, that is, they represent a set of terms, a list of names belonging to the domain of folk botany. This nomenclature contains all the lexical units that are inherited, borrowed or created inside the linguistic community which speaks Romanian, in order to identify these elements of the natural world, that are used by all the social categories from rural and urban settlements and that are opposed to the scientific names. Romanian folk names given to plants are based on the denomination processes and formative patterns specific to our culture, civilization and language and represent a part of the traditional knowledge of the world, passed down from generation to generation.

There are, in the case of the Romanian language, numerous works that have registered the names of these elements of the natural world. Many of the lists, glossaries, lexicons and dictionaries written centuries ago (some as independent works, some as parts of another written works) have recorded phytonyms. As shown by the studies devoted to our old literary texts, Romanian folk plant names are recorded as early 
as the $16^{\text {th }}$ and $17^{\text {th }}$ century religious writings, as Noul Testament de la Bălgrad and Biblia de la București (Chivu, 2013), and works with lexicographic character, eloquent examples being Dictionarium ValachicoLatinum and Dictiones Latine cum Valachica interpretatione. The number of lexicographic works that registered plant names grows significantly during the $18^{\text {th }}$ century. During this century are published: Nomina vegetabulum, written in 1783 by Benkö Iószef (considered to be the oldest list containing exclusively plant names; it registers 620 folk plant names collected from Transylvania in three languages: Latin, Hungarian and Romanian), Verzeischniss der in Siebebürgen wildwachsenden offiziellen Pflanzen, a list written by Petrus Sigerus în 1791 (which includes over 150 phytonyms in 5 languages: Latin-in fact, the official name-, German, Romanian, Hungarian and German), Nachtrag zu des Herrn Profisor Sigeus Verzeichniss wildwachsender Siebebürgisher offzineller Pflanzen, lucrare a lui Samuel Kräutner, din 1793, Plantarum qux in Magno hocce Principatu sponte sua crescent written in 1795 by M. Neustädter (as appendix of another document) and the list of names written by Vszelski Antal in Hungarian, German, Czech, French and Romanian, published in Budapest, in 1798 (reprint of Benkö's list, like all the other mentioned titles) (Orăşanu, 1900, p. 10-11). In the $19^{\text {th }}$ century, the works that list folk plant names multiply. As a result of the development of science and technology in the Romanian territory, this is the century in which the basis for creating scientific terminologies (see Ursu, 1962; Munteanu \& TTâra, 1983), including the field of modern Botany. The interest for Romanian flora rises, the botanists of this century or those working in adjacent fields (pharmacists and doctors, in particular) publish numerous works which include, among other information, folk plant names. Some of the most important publications of the time are: Enumeratio stirpium magno Transsilvanie, written by the German doctor Johann Christian Gottlob Baumgarten (3 volumes; for some species there are given the Romanian names); Alphabetarische Zussammenstellung der saschischen, ungarischen, walachischen und deutschen trivialnamen in Siebebürgen wildwachsenden ober allgemein cultivierter Pflanzen published by M. Fuss in 1847 (list of plant names which contains, besides the phytonyms taken from previous lists, some new ones), Flora Printipatului Moldoveipentru cunoașterea plănturilor crescătoare în Moldova, written by the apothecary I. Szabó in 1841 (which contains Romanian names in connection with German, Latin or Greek names), Notions statistique sur la Roumanie, published in 1849, written by I. Czihac and N. Șuțu (registers over 600 Romanian phytonyms), Enumerarea speciilor de plante cultivate în Grădina Botanică din Iași în anul 1870, a paper authored by Anastasie Fătu, published in "Revista științifică", Flora phanerogama din fostulu districtu al Năsăudului, published in 1881, in "Transilvania” by Florian Porcius, and Limba botanică a țăranului român, written by D. Brîndză, published in "Columna lui Traian”, in 1882. To all of these there must be added the next lexicographical works: Vocabularium pertinens ad tria Regna Nature written by Gh. Șincai (the first Romanian natural sciences dictionary, which contains, besides zoological and mineral names, plant names in four languages: Latin, Romanian, Hungarian and German), Lesicon romănescu-lătinescuungurescu-nemțescu, published at Buda, in 1825 (lists 600 phytonyms), and Vocabulariu de numele planteloru transilvane, romanescu, latinescu (după sistema lui Linné), nemțescu și ungurescu, published by $\mathrm{T}$. Cipariu, in 1847, in the supplement of the newspaper "Organul luminării" (it uses the lists of Sigerus, Kräutner and M. Fuss, to which were added the plant names mentioned by T. Corbea and in Lexiconul de la Buda; this list is organized alphabetically after the Romanian language - the Romanian phytonyms are followed by scientific names and the German and the Hungarian ones; this glossary is reproduced, in 1859, by G. Bariț in "Calendariu pentru poporul român”) (Orășanu, 1900, p. 11-20; Grecescu, 1909, p. 23-24; Bejan, 1991, p. 6-30). Continuing this remarkable progress, the $20^{\text {th }}$ century brings two multilingual dictionaries (Pricop, 2016) that have become reference works in the field of Romanian Botany and Ethnobotany. The first of them is written by Zach. C. Panțu and is entitled Plantele cunoscute de poporul român. Vocabular botanic cuprinzînd numirile române, franceze, germane și științifice, with its first edition in 1906 and the second over more than two decades, in 1929 ${ }^{1}$. The first edition registers 3500 plant

\footnotetext{
${ }^{1}$ Seche (1969, p. 183) considers that the botanic dictionary written by Zach. C. Panțu has three editions: the first in 1902 (entitled Vocabular botanic cuprinzând numirile științifice și populare ale plantelor, published in "Buletinul Ierbarului Institutului Botanic"), the second in 1906 and the third in 1929. However, on the cover of the dictionary published in 1929
} 
names and the second adds 1050 , many of them being listed for the first time (they represent the result of questionnaires and investigations made by the author). The second is the dictionary written by Al. Borza (and his collaborators), Dicționar etnobotanic cuprinzînd denumirile românești și în alte limbi ale plantelor din România, published in 1968. This dictionary registers over 11000 folk plant names which correspond to 2965 plant species. As in the case of the other dictionary, many of these names are mentioned here for the first time (they represent the result of numerous inquiries and information transmitted by various persons). The aim of both dictionaries was to gather Romanian vernacular phytonyms and parallel them with scientific names. Their value is augmented by their multilingual character (also found in the phytonyms lists of previous centuries), which is substantiated by establishing the correspondences between Romanian plant names and plant names of world languages (French and German in the case of Panțu's dictionary, and English, French, Russian and German, in the case of Al. Borza's dictionary) or languages with which Romanian people had numerous contacts (like in the case of Borza's dictionary: Hungarian, Ukrainian, Serbian, the carașovean dialect-Croatian dialect spoken in Banat-Turkish, Bulgarian, Polish). These plant names, often registered with references to the geographical areas where they are used, and their foreign counterparts (which also contribute to the process of establishing etymological links between the Romanian names and foreign ones), offer an overview of the Romanian folk botanical nomenclature and constitute the main source from which the examples used in this article were extracted.

\subsection{Elements that situate the folk botanical nomenclature in the non-structured lexis}

Folk nomenclature, as stated by E. Coseriu in his works, is closely linked to empirical knowledge. Accordingly, the process of plant naming is based on the pre-scientific principles. The empirical nature is confirmed by three elements: the correspondence between folk names, scientific names and extra-linguistic reality, denomination pattern and folk taxonomy.

The comparison between folk plant names, scientific names and extra-linguistic reality, reveals an imperfect overlap between the two nomenclatures. A perfect correspondence does not exist between these three elements. Such equivalence only exists between the extra-linguistic reality and the corresponding scientific nomenclature, which has as purpose the discovery, the research and the denomination of all the existing plants. With the help of modern technology, many unknown plants were discovered. The plant inventory (of lower and superior plants, unicellular and multicellular plants) has grown in the last century, these elements of the natural world being studied and named after the international linnéan denomination pattern (also see Bursuc, 2011). The creators of folk plant names, who relied on the information transmitted by their five senses, could only name the plants that they were able to see or whose effects (often harmful) they could notice. The various species of macroscopic plants (mushrooms, multicellular algx, mosses, lichen, trees, bushes, herbs, vegetables, etc.) growing on our territory have received names because they are large plants, with features that can be easily observed. There are, however, lower inferior plants that only have scientific names, although they have been growing on our territory for a long time (for example, Poria xantha). Obviously, this kind of plants, whose existence could not be deduced, were not named. Taking into account this elements, it becomes clear that between extra-linguistic reality and folk plant names and between the latter and scientific plant names does not exist a perfect correspondence.

The second proof of the empirical dimension is represented by the particularity of the naming process. Unlike the case of scientific nomenclature, in the case of folk botanical nomenclature, denomination is not regulated by formal rules. However, by observing plant names created in our language (which represent the majority of names recorded by various sources), there has been deduced the existence of two denomination patterns: a descriptive one and a metaphorical one (see Milică, 2010)). The descriptive denomination pattern includes all the names that directly refer to a feature considered essential for a particular plant. The metaphoric denomination pattern includes all the names that indirectly refer to the same features as in the case of the descriptive denomination pattern. If a comparison is made between these two patterns, it becomes clear that each plant receives a number (smaller or greater) of folk names,

it is specified that the work represents the second edition. 
some descriptive and some metaphorical ${ }^{2}$. This statistic element indicates that the two patterns are equally productive.

It must also be mentioned the fact that numerous names that reflect distinctive features of plants are used in the folk botanic nomenclature (see Milică, 2010). As shown by the examination of the sources, the traits taken into consideration reflect different aspects of the plants like: colour (gălbiniță-Galeobdolon luteum; roșioară - Calendula officinalis; ruginiță - Asplenium rutamuraria), appearance or shape (buboasă - Potentilla anserina; rotund $\breve{a}$ - Pelargonium zonale; iarbă-ghimpoasă-Crypsis aculeatus), taste (dulceață - Taraxacum offcinale; iuțan - Lactarius piperatus), smell (puturoasă - Arctostaphillos uva-ursi; burete puturos - Phallus impudicus), discharged substances (lăptucă - Russula vesca), place of growth (mlăștiniță - Luzura pilosa; mocioară - Juncus conglomeratus; flori de mălăiște - Equisetum arvense), season of growth, harvest or blooming (primăvăriță - Galanthusnivalis; văratică - Adonis vernalis, noptiță - Mirabilis jalapa; pere sîntămărești), actions or behaviour of the plant (adormițele - Ipomaa; răsuflătoare - Lycoperdum perlatum), its use (in the household: butcă - Lagenaria siceraria; măturişcă - Artemisia annua; in ethno-medicine: buruiană de năduf - Hypericum perforatum; buruiană de roșeață - Echium vulgare; dalac, foaie de dalac - Paris quadrifolia; in magical practices: iarba datului și faptului - Herniaria galabra; iarba dragostei - Botrychium lunaria), and harmful effects (buruiană năroadă - Atropa belladona; burete veninos - Amanita muscaria; iarba-dracului - Datura stramonium).

The link between name and extra-linguistic reality is very strong. Although diversified, folk plant names have a common denominator: the feature considered to be essential. In other words, this heterogeneous system has internal coherence. The same feature is constantly reflected in folk names, some metaphorical, some non-metaphorical. Thus, for mushrooms that have a concave cap or a concave appearance are used the following names: ceșcuţa babei (Dicciotis venosa), copeneață (Lactarius piperatus; Russula cyanoxantha), lighenuţe (Clitocybe geotropa; Paxillus involutus), păhăruțele (Acetabula vulgaris), pîlnioară (Clitocybe infundibuliniformis), scafță (Crucibulum lave; Cyathus striatus), urechiuşe (Aleuria aurantia; Cantharellus cibarius; Peziza badia; Peziza repanda; Sarcoscypha coccinea; Tremiscus helvelloides). Phytonyms such as broasca apei (Potamogeton lucens), buciniş de baltă (Cicuta virosa), cucută de apă (Cicuta virosa), foarfeca bălții (Stratioties aloides), iarba broaștelor (Hydrocharis morsus-rana), limba apei (Potamogen natans), mană de apă (Glyceia aquatica), otrățel de apă (Urticularia vulgaris), rouricăa, plutitoare (Glyceria fluitans) and tidvă de apă (Nymphea alba), are used for aquatic plants, the ecological feature being indicated directly (generally by the use of a term that signifies a type of flowing or stagnant water or by the use of the term "water" itself) or indirectly (through a term that refers to an animal living in the aquatic environment, like a frog). Plants that have flowers shaped like numerous and colourful spikes are called: moț curcanului (Amaranthus caudatus), nasu-curcanului (Polygonum originale), creasta-cocoșului (Celosia cristata; Leonurus cardiaca), because a connection is made between the shape of those flowers and the bird 's anatomical parts they resemble with. Names like: laptele cinnelui (Euphorbia esula), laptelecucului (Euphorbia helioscopica), laptele păsării (Ornithogalum umbellatum), laptele lupului (Euphorbia helioscopia), laptele-stîncei, läptişor (Androsace chamajasme), are used for the plants that release different liquid substances, the mental connection being made between the colour and consistency of the substance in question and the colour and consistency of the animal product.

Folk taxonomy represents the third proof of the empirical dimension and is, as it has been noted in numerous studies, implicit. Unlike the scientific botanical taxonomy, which is independent of the botanical nomenclature, folk botanical taxonomy is encoded in the folk plant names themselves (see Lampman, 2010; Berlin et al., 1973; Friedberg, 1982; Hunn, 1982; Johnson-Gottesfeld \& Hargus, 1998; Morris, 1984). Based on their analysis, one can infer the manner in which the representatives of various communities order lower and superior plants based on the criterion of similarity. A good example is represented by the generic names used for lower plants. From the point of view of scientific classification,

${ }^{2}$ For example, Melissa officinalis is called roiniță, iarba-stupului, floarea-stupilor, mătăcină, mintă-turcească, roiște (Panțu, 1906, p. 289) and Glyceria fluitans is called rourică, fruță, iarbă-dulce, plutitoare (Panțu, 1906, p. 242). 
according to their morphological and phylogenetic features, this group of plants is divided into four categories: algx, mosses, lichens and fungi. From the perspective of empirical knowledge, this large group of plants is divided into two categories: mosses and fungi. The plant group named algæ has no generic term in the Romanian folk nomenclature. Algăa, which meets all the characteristics of such a term, belongs to the scientific language. From the perspective of folk nomenclature, there is no proper generic folk term for this kind of plant category. They did not receive a generic name because they did not bring benefits to the peasant household and were not even viewed as a distinct, homogenous group of plants. For the group of bryophytes, the generic name muşchi is used in folk nomenclature. Small plants, that grow in woods, in green colonies are known by this name. For the lichens category there are, apparently, two generic names: lichen and muşchi. The term lichen, like algă, belongs to the scientific language. Because the term muşchi is used for bryophytes and lichens it becomes clear that the common denominators did not make any difference between the two groups of plants and considered that they belonged to the same category, as they also shared ecological and morphological features.

If algæ do not have a generic term and bryophytes and lichens share one, in the case of the cryptogam plants without chlorophyll two terms are used: burete and ciupercă. The consultation of different sources (Romanian dictionaries, encyclopædias, dictionaries and works about Botany) reveals the next information: the relationship between burete and ciupercă is one of part-whole, burete is perceived as regionalism, whereas ciupercă is the neutral term. For ordinary people, both terms name the lower plants that can be seen with the naked eye, edible, non-edible and toxic, parasitic or saprophytic, that grow on trees and tree stumps, forest soil or meadows, on the edges of the roads, with caps and legs or shaped like a hoof. Over time, they both gained the status of generic term and are considered synonymous. Ciupercăa, unlike burete, is used in the botanical terminology in order to name all the microscopic and macroscopic cryptogams without chlorophyll. For wild superior plants are used the generic names buruiană and $i a r b \breve{a}$ (the denomination patterns [buruiană/iarb $\breve{a}+$ determinant in Genitive/in Accusative] being used extensively in the Romanian folk phytonyms; see also Milică, 2010, 2012).

From the presented facts, it becomes clear that vernacular phytonyms reflect the knowledge of the plant kingdom through pre-scientific principles. All the delimitations and classifications of this botanic nomenclature are made in the extra-linguistic reality, in the order of things. The basis is represented by the information about the world gathered with the five senses with which man is gifted.

\subsection{Elements that situate the folk botanical nomenclature in the structured lexis}

The features that situate the folk botanical nomenclature in the structured lexis are: diatopic, diastratic and diaphasic variation, the variations identified in the phonetic body of some terms, the use of the same name for multiple items of the extra-linguistic reality, the use of multiple names for the same item of the extra-linguistic reality and the etymological diversity of phytonyms.

Based on information gathered from language and ethnobotanical dictionaries, in the case of this nomenclature, there can be identified diatopic, diastratic and diaphasic variations, exactly like in case of common words (see Zamfirescu, 2014a). Of course, this type of information has not been identified in the case of all plant names owing to the gaps in the ethnobotanical literature. However, the identification of this kind of data for many folk plant names proves that variation exists in the case of folk botanical nomenclature. Regarding the geographical variation, different phytonyms are used in different regions of our country. Some examples are: Boletus edulis is called in Moldova hrib and in Muntenia mănătarcă/mînătarcă, Covallaria majallis is named in Moldova lăcrămioare and in Muntenia mărgăritărel, Lappa major is called in Moldova brusture, in Banat captalan and in Muntenia lipan, Leucantheum vulgare is called mărgărit in Moldova, ochiul-boului in Transylvania and tătăişe in Bucovina, and Anemone pulsatilla received the name dediței in Bucovina and suflețele and vinturele in Banat.

In the case of folk plant names, the diastratic data is not very well represented in language dictionaries. However, the mark (bot.) is constantly used to signalize the status of these names as part of a certain domain (in this case, the field of ethnobotany) and the mark (reg.) to signalize the regional use of some 
names (like in the case of fulie - Narcissus poeticus, viorea - Scilla bifolia). More rarely, the marks popular (like in the case of lingura zinei and lingura zinelor) and invechit (for example, in the case of păliciune and pălitură) (according to DLR).

In the case of folk nomenclature, owing to the type of items subjected to analysis, variation can only be studied at the lexical level. Folk plant names are analysed from the perspective of a simple list, wherein there is no interaction between terms. Variation can only be observed in the case of the names that are used in parallel to name a single plant. Etymologically, the terms used to name plants can be inherited, borrowed or created in the Romanian language (the latter can be descriptive or metaphorical, as shown above). The plant names created in our language reflect, directly or indirectly, the feature considered to be essential for the plant in question, the reason for using that particular phytonym being, frequently, obvious. Some of them penetrated into the standard language, some have a regional, dialectal character or, quite rare, represent the mark of an idiolect (for example, the name ciuperci de-ale moașii-Boletus scaber, belonging to the idiolect of a woman from the Făgăraș region, has been recently registered by Constantin Drăgulescu and published in his work in 1995). Thus, the choice of one name implies the choice of a language level and, in the case of the names belonging to the secondary etymological layer (names created in Romanian), the fore fronting of one particular feature. Some examples in this regard are: Allium sativa is called usturoi (name belonging to the standard language, created in Romania and indicating the plant's burning taste) and ai (regional name, inherited from Latin), Brassica oleracea received the names curechi (regional name, specific to Moldova, inherited from Latin) and varză (name belonging to the standard language, inherited from Latin), Rosa centifolia received the names trandafir (term from the standard language, borrowed from Neo-Greek) and roză (a scholarly word), Convallaria majallis is called lăcrămioară (name used in Moldova, created in Romanian by associating the shape of their flowers with the shape of the beads), georgițe (name used in Banat, created in Romanian, which indicates the period in which the plant blossoms) and cerceluşi (phytonym used in Dobrogea, created in Romanian, by the association between the shape of the plant and the jewels worn by women in their ears) and Boletus edulis is called hrib (regional name, used in Moldova) and mănătarcă (regional name, used in Muntenia). Similarly, the use of scientific names instead of folk names (Allium sativa, Brassica oleracea, etc.) implies the reference to the scientific style.

Metaphorical terms belonging to the etymological layer of the phytonyms created in Romanian highlight the creative side of the common denominator. These names reflect the Christian and pre-Christian imagery, the peasant household imagery (with specific objects and animals) and the affective dimension of human beings. The Christian imagery is highlighted by the phytonyms that have is their structure the names given to God, to different Saints or one of the names given to the Devil: cornul-dracului (Spirea aruncus), dintele-dracului (Polygonum hydropiper), muscatu-dracului (Knautia arvensis), scaiul-dracului (Eryngium campestre), lemnul Maicei Domnului (Santolina chame-cyparissus), iarba sfintului Ioan (Actea spicata), poala Sîntei Marii (Chrysanthemum parthenium), isma Maicei Preciste (Tanacetum balsamita), săgeata lui Dumnezeu (Orobanche caryophyllacea). The pre-Christian layer is emphasized by means of phytonyms that refer to pagan entities: coarda ielelor (Glechoma hederacea), hora Rusalilor (Marasmius oreades), lingura Frumoaselor, lingura strigoaicei (Ganoderma lucidum), mana zinelor (unidentified mushroom), smäoaică (Laserpitium latifolium), steagul zînelor (Cuscuta epythinum). In folk botanic nomenclature names that highlight objects specific to the rural life or animals specific for our fauna are often used. Some phytonyms that refer to the peasant household are: lozie (Salix urpurea), mături (Kochia scoparia), măciuca ciobanului (Echinops comutatus), măturele (Cenaturea jurineifolia), soponel (Saponnaria officinalis), troacă (Curcubita langenaria), and some which refer to domestic and wild animals specific to our geographic area are: cuibul-rîndunelei (Neottia nidus), iarba lupului (Doronicum austricaum), limba vacei (Scolopendrium vulgare), măzărichea cucului (Orobus niger), oiță (Anemone nemorosa), ochiu-mîţei (Echium vulgare), ochiul boului (Aster amellus), piperul lupului (Asarum europeum), salata iepurelui (Prenantes purpurea), soricel (Erigeron canadensis). Names containing an ironic or ludic tone should not be forgotten: paştele calului, punga popei, straița popei (Capsella bursa-pastoris), scăetele popii (Xanthium 
strumarium), săpunul popei (Saponaria officinalis), ouăle popii (Helleborus purpuraceus). The affective dimension also reveals itself through the phytonyms that, from the lexical point of view, are diminutives and augmentatives. Some plant names that are or contain augmentatives and diminutives are: mălăoaie (Helianthemum alpestre), răchitan (Lythrum silicaria) and lemnuşcă (Lythrum silicaria), oușoare (Streptopus amplexifolius), pomuşioară (Ribes rubrum), pupezele (Orobus vernus), pufuşor (Trifolium arvense), răchițele (Vaccinium oxycocos).

Apart from the diatopic, diastratic and diaphasic differentiations, folk plant names are characterized by imprecision (for an analysis of the folk botanical terminology see Milică, 2010, p. 77-87). This feature contains two cases: one name is used for several plants and one plant receives several names. In this way the folk plant nomenclature is similar to the common lexis, which is characterized by synonymy and polysemy. Most plants have, on average, at least three-four names, with different origins and created after different denomination and formative patterns (compounding, derivation), depending on the feature considered important for the plant in question. Thus, the plant scientifically named Coronilla varia receives the following names coroniște, ciocîrlan, cunună, cununiță, floare-de-trînși, sămăchișă, unghia-găinii; Holcus lanatus is named flocoşică, iarba-cailor, olei, ovăs-dulce; Lysimachia vulgaris is called gălbăşoară, floare-delungoare, gălbinele, iarbă-de-lungoare, rădăcină-de-lungoare; for Panicum crus-galli the following names are used iarbă-bărboasă, costrei, iarbă-ghimpoasă, mohor, mohor-gros and Levisticum officinale is called leuștean, buruiană de lungoare, buruiana lingoarii. The use of the same for different plants is motivated by the presence of the same feature (colour, smell, taste, place of growth) in the case of the plants in question. The phytonym ghiocei-bogați is used for Leucojum ativum and Leucojum vernum (their flowers resemble the ones of snowdrops); gemănariță is used for Orchis fusca, Orchis morio, Orchispapilionaceaa (their roots are actually numerous geminate rhizomes), gălbinele for Callendula officinalis, Cantharellus cibarius (their flowers are yellow), fruţă for Glyceria fluitans, Poa annua, Poa trivialis, Poa pratensis (they have very thin, long leaves) and dumbravnic for Eupatarium cannabinum and Melittis melissophillum (they both grow in woods).

Another aspect of variation is represented by the phonetic and morphological-lexical variation. Some examples in this regard are: albastră-albăstriță-albăstrea (Centaurea cyanus), bobovnic-bobornic-pribolnic (Veronica beccabunga), bostan-bostănel-bostănei (Curcubita pepo; Moldova), budiană-budiene (Tagetes erecta; Banat, Muntenia), lăuruscă-levușcă-răuruscă (Vitis vinifera), pepenică-pepeniţă-pepenei (Trifolium arvense), porumbar-porombar-porumbrel-scorombar (Prunus spinosa), răchițele (Bucovina)-răcițele (Vaccinium oxycoccos; Moldova), sînzuiană-sînzîiene (Galium verum; Transylvania), solovîrv-solovîrvsovîrc-sovovîrv (Origanum vulgare; Transylvania), tilişcă-telişcă (Circealutetiana; Transylvania), țintaulățintaură (Erythrea centaurium; Transylvania), ghiorele (Moldova)-giorele (Transylvania)-viorică-viorele (Scilla bifolia), volbură-holbură-volvură-holboră (Convolvulus arvensis) ${ }^{3}$.

Additionally, it should be noted that the folk nomenclature contains terms whose origin cannot be always exactly determined, that develop and disappear depending on the development or extinction of some activities and which have, sometimes, restricted usage (Florescu, 2011). Folk names are inherited (ex: ai), borrowed from other languages (e.g., drăgaică < Bulg. dragaika), loan translation after foreign folk names (e.g., gura-leului corresponds to Fr. gueule de lion and to Germ. Löwenmaul) (Bejan, 1991, p. 161) or represent original creations (e.g., nebunariță for Datura stramonium). A close look over the lists containing this type of names and the study of the monograph written by Bejan (1991) show that the folk plant names are not created after rules dictated by a code. Thus, folk names can be synthetic, meaning that they represent a single lexical item (e.g., bănuței), or analytical, meaning that they consist of two or more lexical items (e.g., brînza-vacii). Synthetic names can be basic words (e.g., măr) or derivatives (progressive: pelinariță, desfăcătoare or regressive: agud from agudă). Analytical names are created by compounding from a headterm which receives an adnominal. They can be compounded by coordination (e.g., unt-și-brînză), juxta-

\footnotetext{
${ }^{3}$ It can be noticed that the phytonyms in the case of which phonetic, morphological and lexical variation can be identified often name the same plant.
} 
position (mătrăgună-doamnă-bună), by subordination and compound sentences (mărită-mă-mamă). In the case of compounds by subordination, the head is, generally, a noun (e.g., burete-nebun), but there are some names in which it is a cardinal numeral or a demonstrative pronoun (e.g., treizeci-de-arginți, celperit). There are various adnominal elements: adjectives, nouns, demonstrative pronouns, cardinal and ordinal numerals, adverbs and sentences (e.g., ciupercă albă, burete de mesteacăn, floarea-Sfintei-Marii, buruianacelor-slabi, mazăre-de-patruzeci-de-zile, mere-devreme, fisaică-ce-se-urcă). Subordinated terms can be in Accusative with preposition (ai-de-grădină, buruiană-pentru-negi, burete-cu-creastă, ciupercă-de-pe-coastă, etc.) and without preposition (e.g., burete-roşu), or in Genitive (cucuta-bălților). Often, the adnominal is compounded too, containing few lexical items and, sometimes, it is a head term receiving adnominal elements (e.g., poala-Sfintei-Marii, buruiană-de-durere-de-toate, buruiană-de-beșica-cea-rea, sînge-de-nouăfrați). There must be noted that folk plant names arise from individual creations (based on borrowings and innovative creations based on the established forming processes-compounding, derivation - and on denomination patterns-descriptive and metaphorical) which spread, as any lexical item, over a certain territory. Folk plant names have been created in order to communicate about these elements of the natural world and are passed down from generation to generation orally, are augmented with new names and, inside the community that actively uses them, are subjected to modifications (phonetical, morphological or lexical). For these reasons, their translation is a difficult task.

\section{Conclusions}

Considering these facts, it becomes clear that folk plant names are situated at the border between the structured and non-structured lexis. They belong to the common lexis and to the folk botanical terminology. The folk botanic terms are strongly connected to the extra-linguistic reality, they perform delimitations in the order of things based on the empirical means of knowledge (the senses) and on the cognitive capacity of those who create and use them and, in the same time, they belong to the common lexis, a fact proven by the use of formative and denomination patterns specific to our language, by the presence of deformations, phonetic accidents and variations, by their affective content, expressivity and etymological diversity.

\section{Acknowledgement}

This work was supported by a grant of the Romanian National Authority for Scientific Research and Innovation, CNCS - UEFISCDI, project number PN-II-RU-TE-2014-4-0195.

\section{Bibliography}

\section{A. Lucrări de referință}

Anderson, E.N., Pearsall, D., Hunn, E. \& Turner, N. (2011). Ethnobiology, Wiley-Blackwell, New Jersey.

Avram, A. (1951). Despre originea numelor de plante, „Cum vorbim”, 9-10, p. 35-36.

Bejan, D. (1991). Nume românești de plante, Editura Dacia, Cluj-Napoca.

Berlin, B., Breedlove, D. E. \& Raven, P.H. (1973). General Principles of Classification and Nomenclature in Folk Biology, „American Anthropologist", vol. 75, p. 214-242.

Bolba, D., Stana, D. \& Drăgulescu, C. (2001). Botanica, vol. II, Editura Academic Press, Cluj-Napoca.

Bidu-Vrănceanu, A. (2000). Lexic comun, lexic specializat, Editura Universității din Bucureşti.

Bidu-Vrănceanu, A. (2007). Lexicul specializat în mişcare. De la dicționare la texte, Editura Universității din Bucureşti.

Bursuc, A. (2011). Terminologia botanică din perspectivă coşeriană, „Anuar de Lingvistică și Istorie Literară”, tom LI, p. 111121.

Bursuc, A. (2015). Cîmpul lexical al numelor de rudenie în limba română, Casa Editorială Demiurg, Iași.

Cabré, M. T. (1999). Terminology, Theory, methods and applications, translated by Janet Ann DeCesaris, John Benjamins Publishing Company, Amsterdam.

Canarache, A. (1970). Lexicografia de-a lungul veacurilor. De cînd există dicționare?, Editura Științifică, București.

Chivu, Gh. (2013). Nume de plante în texte vechi românești, în O. Felecan (ed.), „Numele și numirea. Actele Conferinței Internaționale de Onomastică. Ediția a II-a: Onomastica din spațiul public actual (ICONN 2), 9-11 mai 2013”, Baia Mare, p. 1000-1015. 
Coseriu, E. (1986). Principios de semántica estructural, versiune spaniolă de Marcos Martínez Hernández, revizuită de către autor, ed. a II-a, Biblioteca Románica Hispánica, Editorial Gredos, Madrid.

Coseriu, E. (1987). Palabras, cosas y términos, Separata, Universidad de la Laguna, Secretariado de publicaciones.

Coseriu, E. (1994). Arhitectura și structura limbii, în Prelegeri și conferințe, supliment al „Anuarului de lingvistică și istorie literară”, vol. XXXIII, 1992-1993, seria A, Lingvistică, Iași.

Coteanu, I. (1942). Prima listă a numelor românești de plante, Institutul de Lingvistică Română, București.

Desmet, I. (2007). Terminologie, culture et societé. Éléments pour une théorie variationniste de la terminologie et langues de spécialité, „Cahiers du Rifal”, 26, p. 3-13.

Drăgulescu, C. (1992). Botanica populară la Mărginimea Sibiului, Muzeul Brukenthal, Sibiu.

Drăgulescu, C. (1995). Botanica populară în Țara Făgărașului, Editura Constant, Sibiu.

Drăgulescu, C. (2002). Ciupercile în vocabularul românesc, Editura Universităţii „Lucian Blaga”, Sibiu.

Drăgulescu, C. (2012). Botanica populară în Valea Hîrtibaciului, Editura Universității „Lucian Blaga”, Sibiu.

Făgăraș, M. (2007). Botanica sistematică I (Thallobionta et Bryobyonta), Ovidius Universit Press, Constanța.

Fătu, A. (1874). Incercările pentru desvoltarea scienteloru naturali în România, Discursu de receptiune, în Societatea Academică Română, Tipografia Statului, București.

Florescu, C. (2011). Eugeniu Coşeriu şi chestiunea relației dintre terminologiile ştiințifice şi cele populare, „Anuar de Lingvistică şi Istorie Literară”, tom LI, p. 187-197.

Friedberg, C. (1982). Operative Aspects of Folk Classification, „Journal of the Polynesian Society”, nr. 1, p. 102-109.

Grecescu, D. M. (1909). O schițare din Istoria Botanicei. Inceputul, mersul și progresele sale in general și la noi în parte, Institutul de Arte Grafice Carol Gobl, București.

Grințescu, Gh.P. (1920). Despre licheni, Tipografia Universală, București.

Guiraud, P. (1967). Structures étimologiques du lexique français, Librarie Larousse, Paris.

Hays, T.E. (1982). Utilitarian/Adaptationist Explanations of Folk Biological Classification: Some Cautionary Notes, „Journal of Ethnobiology", vol. 2, nr. 1, p. 89-94.

Hunn, E. (1982). The Utilitarian Factor in Folk Biological Classification, „American Anthropologist”, s.n., vol. 84, nr. 4, p. 830837.

Ispas, B. \& Moldovan, V. (1977). Tipurile de polisemie regulată a substantivelor - denumiri de plante în limbile română şi rusăa, „Analele Universității Timișoara”, seria Științe Filologie, XV, p. 155-158.

Johnson-Gottesfeld, L. M. \& Hargus, S. (1998). Classification and Nomenclature in Witsuwit'en Ethnobotany, „Journal of Ethnobiology", vol. 18, nr. 1, p. 39-68.

Lampman, Aa. (2010). How Folk Classification Interacts with Ethnoecological Knowledge: A Case Study from Chiparos, Mexico, „Journal of Ecological Anthropology”, vol. 14, nr. 1, p. 39-51.

Milică, I. (2010). Modele savante şi modele naive în cadrul numelor de plante, „Limba română”, Chișinău, vol. XX, nr. 11-12, p. $77-87$.

Milică, I. (2012). Plant Names, a Cognitive Approach, în V. Polyakov \& V. Solovyev (ed.), Cognitive Modeling in Linguistics, Cambridge Scholars Publishing, Newcastle upon Tyne, p. 105-120.

Milică, I. (2013). Christian imagery in Romanian folk plant names, „Text și discurs religios”, nr. 5, p. 313-334.

Milică, I. (2014). Introducere în stilistică, curs universitar nepublicat (ținut în anul universitar 2013-2014, la Facultatea de Litere, Universitatea „Alexandru Ioan Cuza”, din Iași).

Morris, B. (1984). The Pragmatics of Folk Classification, Journal of Ethnobiology, vol. 4, nr. 1, p. 45-60.

Moscal, D. (2013). Teoria cîmpurilor lexicale. Cu aplicație la terminologia populară a formelor de relief pozitiv, Editura Universității „Alexandru Ioan Cuza”, Iaşi.

Munteanu, Șt. \& Țâra, V. (1983). Istoria limbii române literare. Privire generală, Editura Didactică și Pedagogică, București.

Orăşanu, Șt. (1900). Botanica populară. Note critice, Tipografia Corpului Didactic C. Ispăsescu \& G. Brătănescu, București.

Păltineanu, V. (1982). Terminologia populară şi terminologia științifică în ihtionimie, „Studia Universitatis Babeș Bolyai”, XXII, Philologia, fasc. 1, p. 3-9.

Pricop, A.-M. (2016). Preliminaries to a Typology of Romanian Multilingual Dictionaries, „Philologica Jassyensia”, XII, 2 (24), p. 159-165.

Reinheimer-Rîpeanu, S. (1981). Denumirile româneşti ale ciupercilor, „Limba română, XXX, 6, p. 585-595.

Sava, D. (2006). Algele macrofite de la litoralul românesc al Mării Negre, Ghid ilustrat, Ovidiu University Press, Constanța.

Sălăgeanu, Gh. \& Sălăgeanu, A. (1985). Determinator pentru recunoașterea ciupercilor comestibile, necomestibile și otrăvitoare din România, Editura Ceres, București.

Seche, M. (1969). Schiță de istorie a lexicografiei române, vol. II. De la 1880 pînă astăzi, Editura Științifică, București.

Tănase, C. \& Mititiuc, M. (2001). Micologie, Editura Universității „Alexandru Ioan Cuza”, Iași.

Ursu, N.A. (1962). Formarea terminologiei științifice românești, Editura Științifică, București.

Vascenco, V. (1975). Probleme de terminologie lingvistică, Editura Ştiinţifică şi Enciclopedică, Bucureşti.

Zamfirescu, O. (2014a). Diferențieri diatopice, diastratice și diafazice în denumirile românești de plante inferioare, în „Literature, Discourse and Multicultural Dialogue”, Universitatea „Petru Maior”, Tîrgu Mureș, p. 475-485.

Zamfirescu, O. (2014b). The Characteristics of the Romanian Common Names given to Lower Plants, "Agronomy Series of 
Scientific Research / Lucrări Științifice Seria Agronomie”, vol. 57, nr. 1, p. 283-288.

\section{B. Dicționare și enciclopedii}

Borza, A. (1968). Dicționar etnobotanic cuprinzînd denumirile populare românești și în alte limbi ale plantelor din România, Editura Academiei Republicii Socialiste România, București.

DEX = Dicționarul explicativ al limbii române, 1998, Academia Română, Institutul de Lingvistică „Iorgu Iordan”, Ediția a II-a, Editura Univers Enciclopedic, București.

DLR = Dicționarul limbii române, 2010, Ediție anastatică după Dicționarul limbii române (DA) și Dicționarul limbii române (DLR), Tomul I: $A-B$, Tomul II: $C$, Tomul III: D-Deținere, Tomul IV: Deținut-Dyke, Tomul V: E, Tomul VI: $F-I / \hat{I}$, Tomul VII: J-Lherzolită, Tomul VIII: Li-Luzulă, Tomul IX: M, Tomul X: N-O, Tomul XI: P-Pogribanie, Tomul XII: Pogrijenir-Q, Tomul XIII: R-Sclabuc, Tomul XIV: Scladă-Spongios, Tomul XV: Spongiar-S, Tomul XVI: T, Tomul XVII: Ț-U, Tomul XVIII: $V$-Vizurină, Tomul XIX: Vìclă-Z, Editura Academiei Române, București.

Drăgulescu, C. (2010). Dicționar explicativ al fitonimelor românești, Editura Universității „Lucian Blaga”, Sibiu.

DșL = Bidu-Vrănceanu, A., Călărașu, C., Ionescu-Ruxăndoiu, L., Mancaș, M. \& Pană Dindelegan, G. (2005). Dicționar de științe ale limbii, Ediția a II-a, Editura Nemira, București.

MDA = Micul Dicționar Academic, 2010, Institutul de lingvistică „Iorgu Iordan”, vol. I: $A-M e$, vol. II: $M i-Z$, Editura Univers Enciclopedic Gold, București.

Panțu, Z.C. (1906). Plantele cunoscute de poporul român, Plantele cunoscute de poporul român. Vocabular botanic cuprinzînd numirile române, franceze, germane și științifice, Ediția I, Institutul de Arte Grafice și Editura Minerva, București.

Panțu, Z.C. (1929). Plantele cunoscute de poporul român, Vocabular botanic cuprinzînd numirile române, franceze, germane și științifice, Ediția a II-a, Editura Casei Școalelor, București.

Pârvu, C. (2002-2005). Enciclopedia plantelor, plante din flora României, 4 vol., Editura Tehnică, București. 